\title{
Retrospective Analysis on Intraoperative Neuromonitoring (IOM) of Potential Nerve Injury in Scoliosis Correction Surgery
}

\author{
Omat Rachmat, ${ }^{1}$ Dohar A. L. Tobing, ${ }^{2}$ Ilma Fiddiyanti, ${ }^{3}$ Rr. Nur Fauziyah, ${ }^{4}$ Jenifer Kiem Aviani, ${ }^{5}$ \\ Rr. Anisa Siwianti Handayani ${ }^{5}$ \\ ${ }^{1}$ Faculty of Medicine, University of Sultan Ageng Tirtayasa, Banten, Indonesia, ${ }^{2}$ Faculty of Medicine, \\ Universitas Indonesia, Jakarta, Indonesia, ${ }^{3}$ Faculty of Medicine, University of Jenderal Achmad Yani, \\ Cimahi, Indonesia, ${ }^{4}$ Politeknik Kemenkes Bandung, Indonesia, ${ }^{5}$ Biomolecular and Biomedical Research Center, \\ Aretha Medika Utama, Bandung, Indonesia
}

\begin{abstract}
Iatrogenic spinal injury resulting in paraplegia or paraparesis after surgical correction of scoliosis deformity is a rare complication but is very detrimental to the patient. Intraoperative Neuromonitoring (IOM) has become the gold standard to monitor surgical procedures which has potential risks to damage the spinal cord. This study aimed to retrospectively analyze the role of IOM in predicting the severity and extent of neurological injury during and after spinal correction surgery in adult idiopathic scoliosis cases related to surgical variables. This was a retrospective cohort study conducted at Dr. Cipto Mangunkusumo National Central Hospital, Fatmawati Central Hospital, and dr. Drajat Prawiranegara General Hospital during the period of 20 March 2018 to 20 August 2019. The primary outcomes were intraoperative monitoring status and post-operative neurological deficits status. Confounder data on scoliosis correction degree, intraoperative hemorrhage, and type of anesthesia used during surgery were retrieved. Chi-Square statistic was used in the analysis. Out of the ninety three patients eligible for this study, twenty two patients was detected as positive in IOM assessment. Four of the patients were found to be positive for post-operative neuromuscular defect. Thereby it can be concluded that IOM procedure can effectively prevent neurological deficits post-surgery with $81.8 \%$ specificity and $95.7 \%$ sensitivity among thosepositively detected by IOM. Some of the factors that could potentially influence false positive IOM results such as anesthetic used; dosage and administration procedures; magnitude of the scoliosis correction angle; and amount of bleeding during surgery have to be carefully analyzed.
\end{abstract}

Keywords: Anesthesia, intraoperative neuromonitoring, neurological deficits, scoliosis, surgery

\section{Analisis Retrospektif pada Intraoperative Neuromonitoring (IOM) dari Potensi Cedera Saraf dalam Bedah Koreksi Skoliosis}

\begin{abstract}
Abstrak
Cedera tulang belakang iatrogenikyang mengakibatkan paraplegia atau paraparesis setelah bedah koreksi kelainan bentuk skoliosis merupakan komplikasi yang jarang terjadi tetapi sangat merugikan pasien. Intraoperative Neuromonitoring (IOM) telah menjadi standar untuk memantau prosedur pembedahan yang berpotensi berisiko merusak sumsum tulang belakang. Penelitian ini bertujuan menganalisis secara retrospektif peran IOM dalam memprediksi tingkat keparahan dan luasnya cedera neurologis selama dan setelah operasi koreksi tulang belakang pada kasus Skoliosis Idiopatik Dewasa terkait variabel bedah. Penelitian kohort retrospektif dilakukan di Rumah Sakit Pusat Nasional Cipto Mangunkusumo, Rumah Sakit Pusat Fatmawati, dan RSUD dr. Drajat Prawiranegara selama 20 Maret 2018 sampai dengan 20 Agustus 2019. Hasil primer berupa status pemantauan intraoperatif dan status defisit neurologis pascaoperasi. Data perancu pada derajat koreksi skoliosis, perdarahan intraoperatif, dan jenis anestesi yang digunakan selama operasi diambil. Penelitian ini mengguunakan analisis statistik chisquare. Sembilan puluh tiga pasien memenuhi syarat untuk penelitian ini. Dua puluh dua pasien terdeteksi sebagai positif untuk penilaian IOM. Empat dari pasien ditemukan positif mengalami defek neuromuskuler pascaoperasi. Dengan demikian dapat disimpulkan bahwa prosedur IOM efektif mencegah defisit neurologis pascaoperasi dengan spesifisitas $81,8 \%$ dan sensitivitas $95,7 \%$ dalam IOM yang terdeteksi positif. Beberapa faktor yang berpotensi memengaruhi hasil IOM positif palsu seperti obat anestesi, dosis, dan prosedur pemberian, besarnya sudut koreksi skoliosis, dan jumlah perdarahan selama operasi harus dianalisis dengan cermat.
\end{abstract}

Kata kunci: Anestesi, defisit neurologis, intraoperative neuromonitoring, operasi, skoliosis

Corresponding Author: Ilma Fiddiyanti, Faculty of Medicine, University of Jenderal Achmad Yani, Jalan Terusan Jend. Sudirman No. 40533, Cimahi 40531, West Java, Indonesia, Email: ilmaradiologi@gmail.com 


\section{Introduction}

Iatrogenic spinal injury resulting in paraplegia or paraparesis after surgical correction of scoliosis deformity is a rare complication but very detrimental to the patient. According to data from the Scoliosis Research Society, the prevalence of neurological deficits during spinal correction surgery is at least $1 \%$ of all spinal surgeries. ${ }^{1,2}$ Estimated lifetime economic burden per individual with spinal cord injury ranges from $\$ 1.5$ million for incomplete paraplegia to $\$ 3.0$ million for complete tetraplegia. The annual economic burden associated with 1,389 new persons with spinal cord injury surviving their initial hospitalization is estimated at \$2.67 billion in Canada. ${ }^{3}$

Neurological deficits caused by the iatrogenic spinal injury can range from temporary loss of sensation and muscle paralysis to chronic pain, fatigue, and mental health dysfunction. The potentially debilitating effects on various body systems can reduce a patient's quality of life, leading to depression, anxiety, and loss of selfconfidence. ${ }^{4}$ Some studies estimate that $20-40 \%$ of people with spinal cord injuries are at risk of experiencing temporary depressive disorders during the rehabilitation process. ${ }^{4}$

The use of Intraoperative Neuromonitoring (IOM) on spinal cord function has been shown to reduce the risk of motor deficits or paraplegia. ${ }^{5}$ Intraoperative neuromonitoring (IOM) is a neurophysiological monitoring method that uses electrical currents to assess the functional integrity of the spinal cord, nerve roots, and other peripheral nervous system structures, such as brachial plexus, during spinal surgery. As recommended by the Scoliosis Research Society and the American Academy of Neurology, IOM has become the gold standard to monitor surgical procedures, which have a potential risk of damaging the spinal cord..$^{6,7}$

IOM uses different modalities, including Somatosensory Evoked Potential (SSEPs), Motor Evoked Potentials (MEPs), electroencephalography (EEG), electromyography (EMG), Brainstem Auditory Evoked Potentials (BAEPs), and Visual Evoked Potentials (VEPs). The Somatosensory potential (Somatosensory Evoked Potential/SSEP) monitoring, in which the stimulation is done on the median nerve and posterior tibial nerve, has been widely recognized as a tool to reduce the incidence of spinal cord injury during scoliosis correction surgeries. ${ }^{8}$ However, the use of SSEP alone can only provide indirect evidence of injury to the motor system. ${ }^{8}$ In recognition of this risk, various electrophysiological monitoring techniques that test motor neuron pathways have been developed, including direct cortical stimulation, transcranial magnetic stimulation, and transcranial electrical stimulation, as parts of the Motor Evoked Potentials (MEPs) modality. ${ }^{8,9}$ TcMEPs are sensitive to ischemic nerve tissue and can detect potential motor deficits earlier than SSEP so the occuring spinal cord injuries may be identified and treated sooner. ${ }^{9}$ EEG generally describes the electrical activities on the scalp. The EEG is used to assess the level of cerebral perfusion during vascular surgical procedures for monitoring deep anesthesia or the degree of hypothermia for neuroprotection. Electromyography (EMG) can be used to record the electrical activities produced by the skeletal muscles.

Brainstem auditory evoked potentials (BAEPs) are small electrical potentials occurring due to response to acoustic wave stimuli. These potential waves are relatively resistant to the effects of anesthetic drugs and can be used to monitor nerve functions during ENT surgical procedures. Visual evoked potential (VEP) refers to waves of electric potential stimulated by visual stimuli recorded through the scalp. IOM via the visual pathway is extremely paramount during the surgical process, such as trans-sphenoidal, aneurysm clipping, and reversal of tumors over the Optical nerve. ${ }^{10-13}$

Although the Intraoperative Neuromonitoring (IOM) instrument has long been used in spinal surgery to prevent intraoperative injury, several studies have shown no apparent benefit. ${ }^{10}$ Some evidence suggests that intraoperative monitoring using this tool has resulted in many false positives for predicting neurological damages during operation. ${ }^{11,12}$ However, further analysis is needed as some of the IOM modality procedures, such as MEP, can be significantly influenced by the type and depth of anesthesia. Currently, the anesthetic drugs used during surgery using IOM are TIVA, a combination of propofol and opioids. ${ }^{13}$

This study aimed to systematically analyze the role of Intraoperative NeuroMonitoring (IOM) in predicting the severity and extent of neurological injury during and after spinal correction surgery in cases of Adult Idiopathic Scoliosis related to surgical variables. 


\section{Methods}

This study was a retrospective cohort study conducted at Cipto Mangunkusumo National Central Hospital, Fatmawati Central Hospital, and dr. Drajat Prawiranegara General Hospital, Indonesia, from March 20, 2018, to August 20, 2019. This study had obtained ethical eligibility from the Faculty of Medicine Universitas Indonesia under the ethical clearance Number: 0530/UN.2.F1/ETIK/2018.

Relevant information was retrieved from patients' medical records and hospital electronic database of adult idiopathic scoliosis patients who had undergone scoliosis corrective surgeries and monitored with the use of IOM during the surgery process in 2015-2019. The IOM procedure included the use of EMG, EEG, and/or Evoked potential modalities to assess the nervous structure's integrity. The exclusion criteria were patients who experienced neurological deficits before the surgical procedure.

The following data were retrieved from the database: 1) Intraoperative Neuromonitoring, which categorized as positively significant if the amplitude reduction is more than $50 \%$ or increased latency is more than $10 \%$ compared to the preoperative baseline in median nerveSSEP and posterior tibial nerve-SSEP and there was missing I, III, or V wave in any combination in BAEP and 2) Post-operative monitoring where each patient underwent a post-operative neurological examination by an orthopedic surgeon.

All deficits were documented and compared with the preoperative examination to determine whether neurological findings were present before or after surgery. Patients were assigned to one of four categories: false positive, true positive, false negative, or true negative. Patients who developed neuromonitoring changes that could not be corrected intraoperatively but did not show postoperative neurologic deficit were defined as false positive. Patients who developed intraoperative neuromonitoring changes and demonstrated postoperative neurological deficits were categorized as true positive. Patients who developed new neurologic deficits intraoperatively without neuromonitoring changes were considered to be false negative while patients who did not develop any new deficits were confirmed to be true negative.

With the assumption that the specificity value of the Intraoperative NeuroMonitoring (IOM) examination on the incidence of postoperative spinal cord damage was $98.2 \%$, precision 0.1 , with the incidence of postoperative neurological deficits was $5.2 \%$, to achieve a 2 -sided alpha error of $5 \%$, the minimum required patients data was 93.

Chi-Square Test statistical analysis was used to determine a significant difference of Intraoperative Neuromonitoring (IOM) towards the incidence of a neurological defect in scoliosis patients. Kappa Coefficient of the agreement was used to validate the data.

\section{Results}

Ninety-three patients were eligible for this study. The patients consisted of 28 males and 65 females with a mean age of 21 years (range 16-30 years). The characteristic variables of

Table 1 Characteristic Variables of Patients Underwent IOM and Post-Operative Neurological Assessment

\begin{tabular}{lcccc}
\hline \multirow{2}{*}{ Characteristic Variable } & \multicolumn{2}{c}{ Intraoperative Neuromonitoring } & \multicolumn{2}{c}{ Neuromuscular status Post-0p } \\
\cline { 2 - 5 } & Positive & Negative & Positive & Negative \\
\hline $\begin{array}{l}\text { Scoliosis correction degree (mean } \\
\text { (SD)) }\end{array}$ & $74.45(12.45)$ & $58.03(5.83)$ & $73.75(13.77)$ & $61.38(10.13)$ \\
$\mathrm{N}$ & 22 & 71 & 4 & 89 \\
$\begin{array}{l}\text { Intraoperative hemorrhage (cc) } \\
\text { (mean (SD)) }\end{array}$ & $911.36(77.05)$ & $666.90(84.07)$ & $987.5(103.08)$ & 712.92 \\
$\mathrm{~N}$ & 22 & 71 & 4 & 89 \\
Anesthesia & & & & \\
$\begin{array}{l}\text { Penthothal (N) } \\
\text { Propofol (N) }\end{array}$ & 0 & 42 & 0 & 42 \\
\hline
\end{tabular}


Table 2 Specificity and Sensitivity of Intraoperative Neuromonitoring (IOM) in Scoliosis Correction Surgery

\begin{tabular}{|c|c|c|c|c|c|}
\hline & \multirow{2}{*}{\multicolumn{2}{|c|}{ Variable }} & \multicolumn{2}{|c|}{ Neuromuscular Defect Post-0p } & \multirow{2}{*}{ Total } \\
\hline & & & Positive & Negative & \\
\hline \multirow{4}{*}{ IOM_Status } & \multirow{2}{*}{ Positive } & Count & 4 & 18 & 22 \\
\hline & & $\%$ within & $18.2 \%$ & $81.8 \%$ & $100.0 \%$ \\
\hline & \multirow{2}{*}{ Negative } & Count & 0 & 71 & 71 \\
\hline & & $\%$ within & $0.0 \%$ & $100.0 \%$ & $100.0 \%$ \\
\hline \multirow{2}{*}{ Total } & & Count & 4 & 89 & 93 \\
\hline & & $\%$ within & $4.3 \%$ & $95.7 \%$ & $100.0 \%$ \\
\hline
\end{tabular}

patients who underwent IOM and post-operative neurological assessment were shown in Table 1. Twenty-two patients were detected as positive for IOM assessment. Four of the patients were found to be positive for post-operative neuromuscular defect. Thereby, it was concluded that the IOM procedure could effectively prevent neurological deficits post-surgery with 81.8\% specificity and $95.7 \%$ sensitivity amont those with positive IOM status (Table 2).

\section{Discussion}

Patients who were positive for both IOM and postoperative neurological deficits have a higher degree of scoliosis. Based on a study by Stecker et al., ${ }^{14}$ the large angle of deformity correction in neurosurgical procedures can acutely increase nerve stretch, which can result in disturbances and changes in motor and sensory action potentials that are recorded by the Intra Operative neuromonitoring (IOM) monitor is recorded as changes in MEP and SSEP from baseline values, which can be permanent or temporary.

According to Calancie B who has carried out IOM monitoring during the transpedicular screw insertion procedure, the greater distance between the upper and lower screws and a higher level of spinal surgery correction will increase the risk of nerve scratch in the nerve root. As a result, there will be changes in the MEP amplitude and latency, as well as SSEP on IOM. ${ }^{15}$ Intraoperative hemorrhage was found higher in patients with both positive IOM records and postoperative neurological deficits. According to Pastorelli et al., ${ }^{2}$ neural complications in the form of neurological deficits can occur during and after spinal surgery procedures with massive and acute bleeding. It is not yet known what the maximum allowable total blood loss is to prevent neural complications. However, based on this study, it was identified that a bleeding of 911-987 cc during surgical procedures often results in amplitude and latency disturbances in the MEP and SSEP of Intra-Operative Neuro Monitoring (IOM). ${ }^{2}$

None of the IOM positive patients have undergone pentothal anesthesia. Meanwhile, 22 patients received propofol anesthesia and 4 of them were found to develop neurological deficits post-operatively. Based on a study by Lall et al., ${ }^{16}$ the use of several types of inhalation anesthetics decreases the amplitude and increases the latent phase of IOM. Meanwhile, the propofol-type muscle relaxant has the same effect but to a lesser degree. Halogen and nitrous oxide-based anesthetics affect the amplitude and latency of the SSEP, whereas the MEP examination is generally more sensitive to the effects of anesthesia than SSEP. The dose of propofol is $10 \mathrm{mg} / \mathrm{kg} /$ hour and fentanyl $0.25 \mathrm{mg} / \mathrm{kg} / \mathrm{minute}$ has not been shown to affect the results of amplitude and latency of the MMEP and SSEP in IOM. ${ }^{16}$ In Breitkopf et al., ${ }^{17}$ the predictive value of IOM was shown in 9 of 17 cases with intraoperative worsening of IOM (in MEP and SEP, $>50 \%$ ). The positive and negative predictive values for IOM in the direct postoperative were $52.9 \%$ and $74.2 \%$.

The American Academy of Neurology (AAN) and the American Clinical Neurophysiology Society (ACNS) in 2012 gives a recommendation on the use of IOM through SSEPs and Tc-MEP due to its effectiveness in preventing postoperative nerve damages such as paraparesis, paraplegia, and quadriplegia in spinal surgery (evidence level A). Tc-MEPs are more sensitive to the tibialis anterior muscle, especially for the abductor's muscle, to detect nerve damages. The SSEP and Tc-MEP waves can be stimulated or added with free-run EMG as they can provide 
effectual information to the surgeon during the detection of nerve or nerve root damages due to irritation or nerve root pulling. Even pedicle screw insertion can be evaluated by measuring the conductivity between the pedicle screw and nerve root using EMG. ${ }^{13}$

The use IOM is helpful for early identification of potential neurological deficits early due to limitations of the patient's motor and sensory function monitoring during corrective surgery procedures. Some factors could potentially influence false-positive IOM results. Thus, factors such as anesthesia drugs, dosage, and administration procedures; magnitude of the scoliosis correction angle; and the amount of bleeding during surgery should be carefully analyzed.

\section{References}

1. Hamilton DK, Smith JS, Sansur CA, Glassman SD, Ames CP, Berven SH, et al. Rates of new neurological deficit associated with spine surgery based on 108,419 procedures. Spine (Phila Pa 1976). 2011;36(15):1218-28.

2. Pastorelli F, Di Silvestre M, Plasmati R, Michelucci R, Greggi T, Morigi A, et al. The prevention of neural complications in the surgical treatment of scoliosis: the role of the neurophysiological intraoperative monitoring. Eur Spine J. 2011;20(Suppl 1):S105-14.

3. Krueger H, Noonan VK, Trenaman LM, Joshi P, Rivers CS. The economic burden of traumatic spinal cord Injury in Canada. Chronic Dis Inj Can. 2013;33(3):113-22.

4. Craig A, Wijesuriya N, Tran Y. The influence of self-efficacy on mood states in people with spinal cord injury. International Scholarly Research Notices. 2013;2013:1-6.

5. Charalampidis A, Jiang F, Wilson J, Badhiwala JH, Brodke DS, Fehlings MG. The Use of Intraoperative Neurophysiological Monitoring in Spine Surgery. Global Spine J. 2020;10(1 Suppl):S104-14.

6. Nuwer MR, Emerson RG, Galloway G, Legatt $\mathrm{AD}$, Lopez J, Minahan R, et al. Evidencebased guideline update: intraoperative spinal monitoring with somatosensory and transcranial electrical motor evoked potentials. J Clin Neurophysiol. 2012;29(1): 101-8.

7. Tsirikos AI, Duckworth AD, Henderson LE,
Michaelson C. Multimodal intraoperative spinal cord monitoring during spinal deformity surgery: efficacy, diagnostic characteristics, and algorithm development. Med Princ Pract. 2020;29(1):6-17.

8. MacDonald DB, Skinner S, Shils J, Yingling C. Intraoperative motor evoked potential monitoring-a position statement by the American Society of Neurophysiological Monitoring. Clin Neurophysiol. 2013; 124(12):2291-316.

9. Lo Y, Dan Y, Tan Y, Teo A, Tan S, Yue W, et al. Clinical and physiological effects of transcranial electrical stimulation position on motor evoked potentials in scoliosis surgery. Scoliosis. 2010;5:3.

10. San-juan D, Escanio Cortés M, Tena-Suck M, Garduno AJO, Pizano JAL, Dominguez JV, et al. Neurophysiological intraoperative monitoring during an optic nerve schwannoma removal.2017;31(5):1059-64.

11. Chung S, Park C, Seo D, Kong DS, Park SK. Intraoperative visual evoked potential has no association with postoperative visual outcomes in transsphenoidal surgery. Acta Neurochir (Wien). 2012;154(8):1505-10.

12. Rajan S, Simon MV, Nair DG. Intraoperative visual evoked potentials: there is more to it than meets the eye. J Neurol Neurosci. 2016;7:106.

13. Kim SM, Kim SH, Seo D-W, Lee K-W. Intraoperative neurophysiologic monitoring: basic principles and recent update. J Korean Med Sci. 2013;28(9):1261-9.

14. Stecker M, Baylor K, Wolfe J, Stevenson M. Acute nerve stretch and the compound motor action potential. J Brachial Plex Peripher Nerve Inj. 2011;6(1):4.

15. Park JH, Hyun SJ. Intraoperative neurophysiological monitoring in spinal surgery. World J Clin Cases. 2015;3(9):76573.

16. Lall RR, Lall RR, Hauptman JS, Munoz C, Cybulski GR, Koski T, et al. Intraoperative neurophysiological monitoring in spine surgery: indications, efficacy, and role of the preoperative checklist. Neurosurg Focus. 2012;33(5):E10.

17. Breitkopf M, Bisdas S, Liebsch M, Behling F, Bender B, Tatagiba M, et al. Safety, utility, and clinical results of continuous intraoperative electrophysiologic monitoring in $1.5 \mathrm{~T}$ iMRI-guided surgery. World Neurosurg. 2017;106:198-205. 